\title{
ÖMER ÖZSIPPAHIIOĞLU: "Not a Chameleon absorbing the Color of the Culture they come into Contact with"
}

\author{
Gülden Kazaz Çelik
}

School of Languages, Sabancı University. Istanbul, Turkey

Received: 15 Oct 2020; Received in revised form: 5 Nov 2020; Accepted: 6 Nov 2020; Available online: 13 Nov 2020

\begin{abstract}
Migrant literature has generated interest around the world since 1980s and consistently produced different accounts of the migrants either fictive or factual or fictive formed out of facts. These have been intensively read and hotly discussed under the arguments of diasporic studies. However, most of the time the difference between being diasporic and migrant has been neglected. This seems to be what happens in Elif Shafak's The Saint of Incipient Insanities; the characters there, especially Omer, is the migrant who chooses to leave his hometown as well as all the collective identities defining him to become someone else. Not being a diasporic at all, he is not forced to go to USA neither does he ask to abandon what makes him who he is. On his journey to become someone different, he has encountered all the collective identities he thinks he leaves behind and experienced how badly he fails to create a new identity to himself because of his self-denial. In the end, he has to accept his own failure, which appears to be inevitable once a man is in conflict with who he already is.
\end{abstract}

Keywords-being a migrant, collective identities, identity formation, the sense of (un)belonging.

\section{INTRODUCTION}

Elif Shafak's The Saint of Incipient Insanities is not a novel of diasporic experience; it is the novel of migrants whose life ends up with somewhere in America. Ömer is one of these characters who comes from Turkey to lead a different life while attending a $\mathrm{PhD}$ programme. In the light of Murat Belge's criticism of the migrant, Ömer is the one who makes his own decision to move/migrate to America to adapt himself to the place where he migrates and to gradually turn himself into a man of those who have already inhabited there (a preface written by Belge). Thus, he is obviously neither the forced nor the expelled one; on the contrary, he is the migrant who consciously or willingly chooses to live somewhere different to get rid of what he used to be, for the sake of turning into someone new whom he may like or justify more. In order for such a new identity and individuality, Ömer chooses America as an ideal place to do so and the narrator describes this privileged environment Ömer wants to stay as follows:

Here he was, surrounded by hundreds of faces of dazzling variety, and not even one of them looked familiar. None of these individuals had any idea who he was. Not even one single soul. He was a nobody to each and all of them, so pure and immaculate---absolutely nameless, pastless, and thereby, faultless. And because he was a nobody he could be anybody[...]fully enjoying the exclusiveness of being a total eclipse, the unique freedom of being here, right in front of everyone, and yet seen by no one. The freedom of... (Shafak, 2004, pp.81-2).

Accordingly, there is no one reminding him his past or his previous life in this newly-gained environment, which can help him easily erase what he was once and create an entirely new existence without any specific name or past. In such a reconstructive project of himself, Ömer follows the demands of identity that K. Anthony Appiah analyses in 
The Ethics of Identity. In response to Appiah's criticism (2005, p.107), he wants to "make up any self [he] [chooses]"; yet he ignores the fact that creating identities requires both individual and collective identifications. As to the collective identifications, Appiah believes that they are people's life scripts which are generally associated with being a man/woman, homosexual/heterosexual, white/black, Catholics/ Jews/ Muslims, American/ Turk. However, "these collective identities [are] not as sources of limitation and insult [but rather] as a central and valuable part of what they are" (2005, p.108). Therefore, they should not be ignored; if it is, the reconstruction of a self cannot be succeeded, which Ömer painfully undergoes.

\section{SELF DENIAL: FOR THE SAKE OF IDENTITY FORMATION}

No matter how hard Ömer denies the collective identities belonging to him or at least being a part of him, it is impossible not to witness their impact on his newly-formed life. Ömer is a Turk speaking English with his Turkish accent; thus, his Turkishness is something concealable. For example, when he talks to Abed, his Arab-looking friend, he murmurs: "When you are a foreigner, you can't be your humble self anymore. I am my nation, my place of birth. I am everything except me" (Shafak, 2004, p. 110). It seems Ömer knows that he is the embodiment of his nation although he is not satisfied about it. Throughout the novel, his other collective identities formed by his nation accompany him to reveal him what he conceals from himself. He sometimes misinterprets these confrontations and keeps believing that he can create a new self/ identity to himself out of all collective identities. Once, for instance, he comes across Jesus-told-me-you-had-a-spare-cigarette woman and has to enter into a direct dialogue with her. The moment the conversation starts the woman asks him where he brought that accent from (Shafak, 2004, p. 209). Although this is a clear proof for the inescapable connection between the self and its collective identities, Ömer likes the way she asks it supposing that "as if it were our accents that belonged to nationalities but not necessarily us" (Shafak, 2004 , p. 210). Indeed, accents are certainly belonged to nationalities which explicitly belong to people.

Ömer striving to get rid of his collective identities believes that he "[is] better acquainted with [American] culture than his own" (Shafak, 2004, p. 75); he feels "somehow not that foreign" (Shafak, 2004, p. 73) in this new place, America.
However, he is badly mistaken since who we are is closely related to what we are as Appiah stresses in the preface of The Ethics of Identity (2005, p. xiv). It seems evident that this cannot be thought separately; what we are is the combination of our collective identities that we need to accept their life scripts. If this is accepted, then it will be probable to work on constructing new and positive lifescripts onto them (Appiah, 2005, p. 109). Yet, as long as collective identities are neglected, the attempts to construct new identities demonstrating who we are turn into a mere dream or a fantasy. This perfectly explains why "Ömer Özsipahioğlu [is], in every single layer down to the lowest echelons of his soul, demoralized and unsettled" (Shafak, 2004, p. 75) in America.Although Ömer moves to America in order "[to run] away from the person he was" and "not to be himself anymore" (Shafak, 2004, p. 77), he ends up with an existence of "self-destruction" (Shafak, 2004, p. 266) and on the way of becoming someone different with a new identity, he suffers a lot. To exemplify, he suffers a lot from his own name which continuously reminds him that he does not belong to this newly adapted place. In contrast, his name hauntingly attaches him to his nation, one of the collective identities he tries to leave aside. This might be the reason for which he gets so obsessed with his dots and explains why he tries to put them back to their usual place whenever possible. At this moment, the narrator makes a comment of Ömer's obsession stating that "[w]hen you leave your hometown behind, they say, you have to renounce at least one part of you. If that was the case, Ömer knew exactly what he had left behind: his dots!" (Shafak, 2004, p. 5). His dots are not only the part of him but also the part of one of his collective identities: his nation.

It is obvious that Ömer craves for his name which lacks its dots whereas the narrator justifies the fact that "his dots [are excluded] for him to be better included". In fact, the lack of the dots does not guarantee his smooth insertion into the American context. Contrarily, it becomes the eternal signifier of his Turkishness. What is worse, if the "names are the bridges to people's castles of existence" (Shafak, 2004, p. 22), as the narrator describes, Ömer certainly lacks such a proof validating his existence, which upsets him a lot. "[T] he problem of his surname being dotless and far too long to fit into a tag on a mail-box" (Shafak, 2004, p. 20) makes him mourn after the loss of his nation, one of the most distinctive collective identities forming who he is. He says, 
When I write my name in Turkish, it has dots. In English, I lose them. It sounds stupid, I know, but sometimes I lament losing my dots. Therefore, those dots up there must be mine, take care of them (Shafak, 2004, p. 216).

Ömer loses his accent, language as well as his name with its dotseach of which structures his nationality,one of the determining factors to shape his collective identities. At the end of such a loss, he is not certainly sure whether "those dots up there" truly belong to him although they supposedly belong him.

In addition to his denial of his nation, Ömer does not seem as a man of Muslim countries. He is not only addictive to alcohol, which is one of the accepted sins of Islam, but also indifferent to praying or talking to/about God throughout the novel. This is most possibly why he is depicted as a drunk at the beginning of the novel in stark contrast to Abed, his pious Muslim roommate whom, "despite the apparent similarity (being both from Muslim countries), and despite being close friends, [he] might not have that much in common" (Shafak, 2004, p. 3). This contrast is also emphasized by Abed while he is discussing with Ömer in this way:

I am a pious Muslim whereas you are a lost one.

"A lost Muslim..." Ömer gallantly [repeats], closing his eyes in some kind of an ecstasy as if expecting a "lost Muslim animation" to appear before his eyes...As nothing [appears], he [has to reopen] his eyes, and observe some deep sense of wretchedness filling the void where he [expected] the image to appear (Shafak, 2004, p. 14).

Even though Ömer tries to envisage a person who loses himself and his religious beliefs, he fails and consequently he comes up with the emptiness, the inexplicable. Once through the end of the novel, Ömer is exposed to talk about religion and God when he is with his beloved Gail but he, "Ömer the Infidel" (Shafak, 2004, p. 337),instantaneously stops her claiming that she is also not a type of person who believes "in these things" (ibid).Obviously Ömer avoids speaking of these religious issues as he loses his faith in them; he is namely "a born Muslim who [wants] to have nothing to do with Islam or with any other religion" (Shafak, 2004, p. 14).

What Ömer wants to leave behind seems more than these indeed. He has to sacrifice his childhood memories as well as his family ties, including his beloved cousin Murat who means a lot to him. The narrator tells their common past in such a deep nostalgia:

ISSN : $2456-7620$

https://dx.doi.org/10.22161/ijels.56.1
It [is] sad the way things [turned out]. It [is] sad because everything was so different once. Their mothers being not only sisters but also neighbors who spent more time in each other's houses than in their own, and they being of the same age, it was inevitable for them to pass all their childhood glued to one another. Back then they had so many things in common, or maybe, perhaps, each merely echoed what the other voiced. They collected the same things: stamps, foreign coins, and girls' hairbands [...] In camaraderie they dreamed of the same professions [...] read the same books [...] supported the same team [...] They were like peas in a pod then, with interests, accomplishments, and even failures so much alike, and to continue the resemblance, they started dating girls that were close friends [...] Such was the destiny of their camaraderie (Shafak, 2004, p. 162).

Ömer and Murat were such close, "as close to one another as two trains stationed side by side at some transitional station" until "the moment of departure [came]" (Shafak, 2004, p. 163). Afterwards, Ömer left METU, the university, and the department, Industrial Engineering, as well as so many memoirs and experiences he went through with Murat. That leads Ömer to leave his cousin behind, move to Istanbul to study in the Department of Political Science in Bogazici University. He achieves considerable success in his classes unlike his disappointing failure in his affairs with the other sex, which eventually results in more drinking and more irregular life full of pains and laments (Shafak, 2004, p. 165).

All these imply the idea that his attempts to rebuild himself in denial to his family ties as well as all the other collective identitiesseem to be in vain. No matter how hard he tries to have a new identity different than Murat's, he fails and thereby he decides to give a new try in a different place where he is accepted as no one. Nonetheless, this does not go in a way Ömer plans; leaving everything and everybody he values behind, he encounters a sense of loss which hinders his chances of constructing a new existence in America. The narrator shares how he feels as follows:

Soon Ömer found himself wallowing in a set of existential questions, such as what was he doing (not in this plane but in life), where was he going (again for that matter), why was he leaving his country, what difference would it make to have a Ph.D. in political science in America, was that the real reason why he was on this plane or was he sort of running from the person he was, and so on (Shafak, 2004, p. 77). 
It is obvious that his mind is full of questions and anxieties even on his way to America; he seems unsure about his moving to a new place. Therefore, the idea of moving to America does not sound as if it were a well-thought decision; it appears to be a suddenly-settled one instead. This may explain why he is not so prepared to move to America "with wheelless suitcases" which lead him to drag along them "through the rush-worn corridors under the pitying gaze of nocturnal passengers" (Shafak, 2004, p. 80). This scene evokes a sense of pity towards Ömer but its effect somehow changes when Ömer "thought to himself, it was sort of ironic that his very first act in this new city should be sweeping of its dirt" (ibid). It is ironic in a sense that the place where he imagines to create a new identity and existence to himself makes him clean its dirt but it is not ironic in a way that the dirt he sweeps of arouses in the reader a sense of foreboding: as he does not precisely know why he moves there, he tends to get lost in the borders of this new territory as well. So, this is the very first experience of Ömer in America which does not sincerely welcome him.

It is not so late that he realizes "the difficulty of being a non-American in America" (Shafak, 2004, p. 108) since he does not find any appropriate place to locate himself. The first attempt he makes to belong to somewhere is his search in Abed and Piyu's house although to be accepted in this house as one of them is not as easy as he thinks. The first question they ask is where he is from; this is certainly not a prerequisite for his staying there but it is a strong reminder to Ömer about who he is. He once again encounters one piece of his collective identities and once again ignores its relation to him. His nationality is not the only question Abed and Piyu ask; they have a list of questions interrogating his life which "are not intended to judge [his] personality or morality, but only to gauge how well [they] will get along" (Shafak, 2004, p. 88). Yet, these questions annoy him and after the first three questions he "[starts] eing everything they [ask]" (Shafak, 2004, p. 89) as a token of his annoyance and disturbance. Finally, Ömer is accepted as a flatmate at the end of some private talk away from him.

This procedure and weird test are all to test if Ömer is sensitive to garlics or not; yet the way the questions are posed and the way Ömer answers show that the condition that one sets to make the other belong somewhere can be as unreliable as the one which puts someone somewhere randomly. That is to say, there is no definite way to be accepted in or belong to somewhere; it is all perchance.

\section{CONCLUSION}

Throughout the novel, Ömer does not follow the demands of identity that Appiah analyses. To start with, he does not recognize his collective identities such as his nation and religion. Even if he does, "recognition means...not mere acknowledgement of one's existence" (Appiah, 2005, p.107). He also needs to search the authenticity of his newly-constructed self. "Authenticity speaks of the real self buried in there, the self one has to dig out and express. It is only later[...] that the idea develops that one's self is something that one creates, makes up, like a work of art" (ibid). However, Ömer is "unable to be his usual self" (Shafak, 2004, p. 229); at any rate, he is incapable of having any access to his real self and thus what he does is to pretend, which "[bothers] him most in life" (Shafak, 2004, p. 214). He says,

'I guess I envy Piyu and Abed. They know so well what they would like to accomplish in life. Why did you come to America? What will you do upon graduation? Where is home? They know the answers! But me... I am only pretending... (Shafak, 2004, p. 215).

If authenticity is a matter of being true to who you already are as Appiah states, Ömer is certainly unaware of his true self since he does not know any of the answers of these questions which may help him to dig out his true self.

In the end, Ömer turns into "the clown in the mirror" (Shafak, 2004, p. 279) whose reflection is not familiar to himself any longer. He [sighs and sighs], getting more transparent with each sigh, like a floating shadow riding on puffs of air, his toes barely skimming the rough rug of Reality" (Shafak, 2004, p. 246). He is literally becoming no one that he had aimed before he moved to America. He becomes a shadow, the mere reflection of a form. Indeed, even though he accepts his transformation into the shadow, he refuses the fact that he really has it (Shafak, 2004, p. 261). Namely he does not even belong to this shadow self. Such a transparent existence makes him question himself, his newly constructed identity/existence, more. "Who am I, what do I want, do I really have to want...someone, something...do I really have to be... someone, something?" (Shafak, 2004, p. 262); nevertheless, what he eventually has nothing except for admitting that "he [is] afraid. Afraid of really, truly loving someone, and then losing that person, afraid of settling down and belonging to somewhere, be it family, country, or marriage, afraid of the irreversibility of 
life, and the sternly linear flow of his eternal enemy: time" (Shafak, 2004, p. 240).

At the end of the novel, Ömer comes back to his country, Istanbul, which is the city of "the negation of a negation" (Shafak, 2004, p. 329) where "each sound is met with a disagreeing reverberation" (ibid). Istanbul is a perfect place which evokes the sense of being in-between or neitherbelong-to-here-nor-there; if the setting of the finale is considered, the importance of location is getting more and more significant since it does not take place anywhere in Istanbul but on the Bosphorus Bridge, which separates the Asian side of the city from the European side. The last time the readers see Ömer, he is on this bridge watching the running of Gail over the barriers. Petrified, he does not prevent her from leaving him (Shafak, 2004, p. 349). So, what Ömer will do next, whether he goes back to America, the place where he hoped to construct a new identity and existence, or stays in Istanbul, the place where he had previously failed in constructing a new identity and existence, are ambiguous. Yet, it is quite clear that Ömer is not the migrant who easily adapts to the place he migrates and changes into a man of those who have already settled there. He may not be forced or expelled as moving/migrating to a new place is his own decision but even he may not be suffering from any diasporic experiences, it does not necessarily mean that he as the migrant does not suffer at all. Hence, being a migrant might lead to different challenges if the one thinks and behaves against who he actually is like Ömer who "is not a chameleon absorbing the color of the culture [he comes] into contact with" (Shafak, 2004, p. 265).

\section{REFERENCES}

[1] Appiah, A. (2005). The Ethics of Identity. Princeton: Princeton University Press.

[2] Dufoix, Stéphane. (2011). Diasporas. (I. Ergüden, Trans.) . (M. Belge, Prefaced.). Turkey: International Hrant Dink Foundation Press.

[3] Shafak, Elif. (2004). The Saint of Incipient Insanities. New York: F.S.G. Books. 